\title{
WILEY

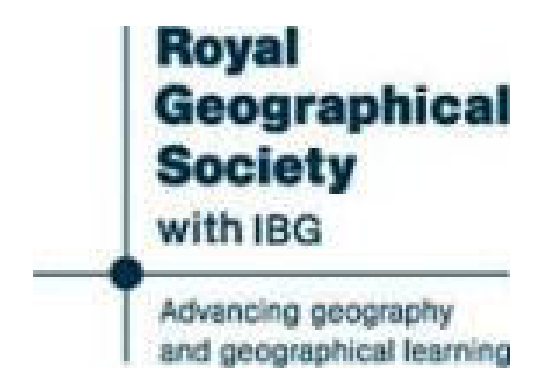

Journey from Bunder Abbass to Mash'had by Sistan, with Some Account of the Last-Named Province

Author(s): F. J. Goldsmid

Source: Proceedings of the Royal Geographical Society of London, Vol. 17, No. 2 (1872 - 1873), pp. 86-92

Published by: Wiley on behalf of The Royal Geographical Society (with the Institute of British

Geographers)

Stable URL: http://www.jstor.org/stable/1799254

Accessed: 16/06/2014 04:29

Your use of the JSTOR archive indicates your acceptance of the Terms \& Conditions of Use, available at

http://www.jstor.org/page/info/about/policies/terms.jsp

JSTOR is a not-for-profit service that helps scholars, researchers, and students discover, use, and build upon a wide range of content in a trusted digital archive. We use information technology and tools to increase productivity and facilitate new forms of scholarship. For more information about JSTOR, please contact support@jstor.org. 
Quebec and Nova Scotia.' By A. R. C. Selwyn. Halifax, 1872. Donor the author. 'A Visit to Shamyl's Country in 1870.' By E. Ransom. 1873. Donor the author.

Accessions to the Map-room since the last Meering of Jandary 13тн, 1873.--Sketch-map of the South-west part of the Coast of New Guinea, showing the tracks of Beccari and D'Albertis, April, 1872. Constructed and presented by Guido Cora, of Turin. Map of the Basin of the Rusizi, and north portion of Tanganyika, from the routes of Stanley, Burton, Speke, and Livingstone, \&c. Constructed and presented by Guido Cora, of Turin. Map of Switzerland, showing meteorological observing stations. Presented by the Swiss Board of Works. Sketch-map of the Telegraph-line from Port Darwin to Adelaide. Presented by F. R. S. Dutton, Surveyor-General, Adelaide. Map of the World, showing the Submarine Cables already laid, and those projected. Presented by William Abbott, Esq., Stock Exchange, London. Map of Augusta County, Virginia. Prepared under the direction of Major Hotchkiss, Topographical Engineer of Washington College. 2 sheets. Presented by the author. Admiralty Charts on 35 sheets, bringing the Admiralty series up to the present date. Presented through Admiral G. H. Richards, с.в., Hydrngrapher.

The President said the subject of one of the papers to be read to the meeting was the province of Seistan, a country of considerable interest politically, ethnologically, and historically. It was a sort of debateable ground between Persia and Alghanistan, and was the native home of Persian romance, which in Persia occupied the place of historical associations. Any one who pretended to be conversant with Persian society must have at his fingers' ends the romance of the country, and Seistan was the land of Rústum and his associates, of whose life modern Persian conversation and manners were in reality a reflex. Sir F. Goldsnid had been sent out to Seistan in order to arbitrate between Persia and Afghanistan on the boundary question, and he had performed his difficult and dangerous task in a most satislactory manner. He was accompanied by General Pollock, and assisted in his surveys by Major St. John, R.E., Major Lovett, R.E., and Mr. Blanford, all of whom were present at the meeting. He would now call upon Sir F. Goldsmid to communcate his own paper :-

1. Journey from Bunder Abbass to Mash'had by Sistan, with some Account of the last-named Province. By Major-General Sir F. J. GoLDSMID, K.C.S.I., C.B.

\section{[ABstract.]}

Sir F. Goldsmid and party landed at Bunder Abbass on the 21st December, 1871, with the intention of proceeding to Sistan, to carry into effect the Boundary Settlement with which he had been entrusted, and, having obtained horses, on the day before Christmas Eve they started for the interior. 
Travelling in a north-easterly direction through a country very sparsely populated, they crossed a rocky range into the plains through which runs the river known as the Rud Khaneh-i-Duzdi, which here, flowing from west to east, turns south at Minab, thence finding its way to the sea. Camp was formed on its left bank, where they had expected to meet with a "Mishmandar" (or caterer), depnted by the Governor of Kirman to attend on them. He was reported, however, to be awaiting them at Khànn, a village some 30 or 40 miles distant, but did not appear until Doulat-abad was reached, having been two months away from Kirman in search of them.

From Doulat-abad, a long march of 30 miles was made into the mountains, the passage across which was effected by the Deh-Bakri Pass (7800 feet), previously crossed by Major Murdoch Smith, R.E., in 1860. A number of vexatious circumstances delayed the party a whole day when near the summit; but the passage was successfully accomplished on the next, and a forced march of 35 miles brought them to Bàm, where they were met by Major B. Lovett and Quartermaster Sergeant Bower, R.E., with one or two native attendants.

The people in the tracts passed through appeared to be a poor, inoffensive race, thoroughly under the control of their chiefs, some of whom evinced a decided partiality for intoxicating liquors. Sir F. Goldsmid was of opinion that any Persian-speaking Englishman, armed with a letter from the Governor of Kirman, or any high local authority, might travel in the fine Rudbar and Jinoft districts with safety, and even a certain degree of comfort.

After four days spent at Bàm (of which place the author had previously submitted an account to the Society), on the morning of January 12th, 1872, a march of 23 miles was made in a s.s.e. direction to the village of Kruk, approaching the line of mountains they had previously crossed, which has no generic name of its own, but is distinguished by the names of its prominent points.

At Azizabad, 17 miles E.N.E., four days were occupied in preparing for the march across the eastern portion of the Kirman Desert, the road still following the same direction, through the richly-cultivated and fertile plains of the Narmushir, to the comparatively populous town of Fahruj, on the Azizabad River.

From this place to Sekuha in Sistan is from 225 to 230 miles, in a general direction of north-east by east, across the desert. A halt of five days was made at Nusrutrabad, nearly midway, to await the arrival of a party of Sistan Beluchis sent to meet them. Pushing on from the last-mentioned place, a wild, mountainous region was entcred, some of the peaks observed being of great height, and 
capped with snow. The night was passed in a gorge of the mountains.

A march of 35 miles from this last camp brought them to the plains of Sistan, unmistakeably distinguished from the stony slope, by which it is reached from the south-west; and on February 1st, they entered Sekuha, the modern capital of Sistan, built amidst utter desolation and ruin, in a country so rugged and cut up as if it had been purposely rendered roadless and inapproachable.

It is somewhat embarrassing at the present day to define the limits of the province of Sistan. We may suppose two territories, one compact and concentrated, which may be termed "Sistan Proper," the other detached and irregular, which may be termed "Outer Sistan." Sistan Proper is wholly in possession of Persia, and is bounded on the north by the "Naizar," or reed-bed, which fringes the "Hámún" expanse; west by the "Hámún" itself; south by a line comprising Sekuha, and all villages and lands watered by the Sistan Canal; and east by the old bed of the Helmund, from the "Band" at Kohak to the mouth. The total area may be estimated at 947 square miles, with a mixed population of about 45,000 ; of whom 20,000 are Sistanis, 15,000 settlers from other parts of Persia, and the remainder Buluch nomads.

The soil is principally sand and clay alluvium, of proved fertility; but there are neither hills nor trees. It is well watered by rivers and canals: wheat or barley is, perhaps, the staple cultivation, but peas, beans, oil-seeds, and cotton, are also grown, and melons are abundant. Grazing and fodder were also met with.

The Hámún expanse, before alluded to as bounding the province on the west and north, is, for the most part, dry, and its existence as a lake can only be certified, at the present time, by the pools of water, formed in the early spring at the mouths of its principal feeders; yet its limits are well marked on the north and south: on the former by the "Naizar," and on the latter by a clay cliff of irregular height, called the Sangbar.

Sistan may be compared to Sind, in most of its features and characteristics, and, like it, is dependent upon canals, and occasional inundations, for water-supply; while well-defined beds of dry canals prove the pre-existence of an extensive water-system, similar to what may be observed in that part of India. The principal canal of Sistan, confounded by some writers with the parent river, carries the waters of the Helmund into the heart of the country, and is diverted from the river by a large "Band" or dam, protected from wilful damage by a fort and tower. By means of the main and branch 
canals, water is conveyed to almost every town and village in Sistan Proper, thus offering facilities for an extensive grain-cultivation.

During the stay of the party, from the end of January to the middle of March, the thermometer ranged from $5^{\circ}$ above zero, to a maximum of $93^{\circ}$, a low temperature prevailing, with strong continuous winds; but the season was an exceptionally severe one. Provisions were plentiful.

Of Outer Sistan, Chakansúr district forms the chief and most cultivated portion, and lies on the right bank of the Helmund, east of its embouchure in the Hámún, embracing an area of 120 miles in length, and some 30 in breadth. The portion south of this, or up the Helmund, is little cultivated, excepting along the river-bank; in addition there is another large tract on the opposite side of the river, extending from above the dam to the gravelly soil below the ranges dividing Sistan from Beluchistan, including an extent 40 miles north and south, and 90 east and west. The Outer Sistan population consists of Buluch Nomads, chiefly of the Sanjarani and Toki tribes. The fort in which the Sirdar resides, surrounded by about 150 houses, and bearing the name of Chakansúr, is the only place that may be designated a town, with the exception of Kaddeh on the eastern limit.

On the 11th of March, after a stay of some weeks in Sistan, a move was made towards Lash Juwain across the northern frontier, with a view of reaching Tehran viâ Mash'had, the capital of Khorasan. The district of Lash Juwain, or Kokat, has been already described by Femir and Conolly. It is of small extent, little populated, and sparsely cultivated. The fort of Lash stands on a perpendicular cliff 400 feet high, overlooking the Farah River. The road from Lash to Birjand, as far as the village of Durah, crosses a dreary undulating plain ; further on, however, the country becomes more diversified, mountains and plains being met with at intervals, and much wild vegetation and cultivation where inhabited. The general direction of the hills appeared to be north-west and southeast, the valleys in many cases being shut in like an amphitheatre. During this portion of the route, Sardar Ahmed Khan, brother of the Governor of Juwain, took leave of the party. Sir F. Goldsmid spoke highly of his invariable courtesy and attention while in their company. He was a remarkably shrewd and intelligent man, and spoken of by Conolly and Khanikoff in equally favourable terms.

Birjand has been for many years the principal city of the "Kaianát," or divisions of the large Kaián district, superseding the original headquarters; the houses are of the ordinary Persian type, but a new bazaar of modern style is in course of construction. 
On approaching the town the party were received by a cavalcade, headed by the youngest son of the Amir of Kaián, owing to the illness of his elder brother, who held the command during their father's absence at Sistan. A halt of three days was made here, to await a supply of camels. Kaián was reached on the 6th April, the intervening stages being Chink, Seh-Deh, and Rùm, neither of which had been previously visited by Europeans. The recent famine is said to have reduced their populations to less than half.

Chink, the first named of these, is by far the most picturesque; it is situated at the eastern extremity of a basin of high land, over which loom the crests of majestic mountains, in the tracts north of Birjand, where the altitude is not far short of 8000 feet above the sea-level : near it are many fruit-trees and gardens, while extending down the valley in narrow strips, or rather steps, are beds of green cultivation, and a stream of water running in a westerly direction down the valley. There were many such valleys near the encampment, the mountain tops clothed in reddish and greenish hues, the smoothness of their outline being relieved by massive boulders. At Seh-Deh were seen some beautiful specimens of the carpets for which the district is famous.

Kaián, the old ceapital, is built upon a plain almost surrounded by mountains; it covers a considerable extent of ground, and has large and numerous walled gardens. It is marked on modern maps as lying 60 miles south, instead of the same distance north of, Birjand. The population consists of some 500 families, chiefly Sâiads, Mullahs, and the like; they are bigoted and intolerant, acknowledging no resident temporal power out of their own community. This being their first acquaintance with Europeans, their inquisitiveness became rather troublesome.

The escort accompanying the travellers consisted of footmen only, collected together from stage to stage, and badly equipped,- no mounted escort being procurable either at Birjand or Kaián, on account of the scarcity of fodder for horses; and as the country to be traversed between the latter place and Bajistan was reported to be infested by Turcoman robbers, it became necessary to make some slight detour from the usual road, but although there were constant rumours of the approach of these unpleasant customers, the journey was accomplished unmolested. All the stages passed offered some attraction in points of scenery; the climate was almost perfect. The villages of Girimanj, Dasht-i-Biaz, and Kakhk are pleasantly situated; at the latter is the shrine of Sultan Muhamad, brother of Iman Razi, conspicuous by its dome with painted tiles of fanciful design, and evidently held in great esteem. 
At the village of Zibad, the party were the cause of great alarm to the inhabitants, who mistook them for a party of marauders, and it was some time before confidence was restored.

A dreary march of 24 miles brought them to Bajistan, where a day's halt was made; a manufacture of silk, and woollen cloth is carried on here, and the specimens seen were of a superior quality. Passing through the village of Iman Deh, on the road to Turbat, the next place of any importance, a letter was received from the Governor of Mash'had in reply to one sent by Sir F. Goldsmid, advising him of their intended visit. On nearing Turbat they were met by two parties of horsemen, one of them headed by the governor, orders having evidently been received to treat them with dúe honour. The town is most advantageously situated, and surrounded by gardens and cornfields, bearing testimony to the fertility of the soil ; cotton and opium were also cultivated, but it had not escaped the blighting influences of the recent famine. The governor was a handsome, energetic man, and enterfained the travellers with marked and unremitting attention; the remainder of the distance to Mash'had, about 80 miles, was accomplished in three stages, by way of the Godar-i-Beidar Pass (2250 feet above Turbat); although this road had an unfavourable repute, owing to recent Turcoman raids, the presence of a strong escort rendered extra precaution unnecessary.

Mash'had is a city of special sanctity and repute, and is held in high veneration by the whole Muhamadan world, containing, as it does, the shrine of the Iman Raza. On reaching the high lands, whence a view of its minarets and golden dome is first obtained, it is the custom of orthodox Persian travellers to bow towards it reverentially, in acknowledgment of the holiness of the locality. The Arabic word Mash'had signifies a place of martyrdom in the cause of religion, and doubtless applies to the death of the Iman in prison by poison, yet it is greatly to be feared that, notwithstanding the odour of sanctity encircling the Mashadi, he had no higher morale than his coadjutors.

The city has been frequently described by previous writers, but although possessing many attractions, the enervating effects of its luxurious surroundings upon Europeans rendered a prolonged stay by a surveying party undesirable.

Among the many objects of interest met with, the most remarkable was considered to be the "Rig-i-Rowan," or moving sand, which tradition makes the resting-place of Iman Zard : it is situated at a hill between Kalek Kah and the Harut River, near the PersoAfghan frontier, where deep drift-sand had become massed in a long voL. XVII. 
broad steep line from top to bottom of the southern face, the rest of the surface being quite clear, whilst a mysterious noise is produced by the shifting sand at uncertain periods. It is a place of pilgrimage for Muhamedans, who come to pay their devoirs at the supposed shrine.

The paper will be published entire, with a map, in the next volume of the 'Journal.'

The President said the route taken by Sir F. Goldsmid had never been followed by any European traveller since the days of Marco Polo. Only three Englishmen had visited Seistan previous to the late expedition. The first was Lieut. Conolly, the second Dr. Forbes, and the third was an officer sent there from Kandahar thirty years' ago. All these gentlemen died violent deaths during the Afghan war. The province of Seistan was so little known, and was of so much political interest at present as a debateable land between Persia and Afghanistan, that he would venture to supplement Sir F. Goldsmid's paper by a few notes on the ancient history and comparative geography of this part of the East.

\section{Notes on Seistan. By Major-General Sir H. C. Rawlinsor, k.c.в., President R.G.s.}

'This paper will be published in the 'Journal,' in connexion with the foregoing one by Sir F. Goldsmid.

Major St. JoHN said he left Teheran, where he was acting as Director of the Persian Telegraph, for Bushire about the 20th October, 1871, and did not reach the latter place until the end of December. On the last day of 1871 he left Bushire by sea for Gwader, where he arrived seven days after; there he met with Mr. Blanford, who had been deputed to accompany him to investigate the geology and zoology of Beluchistan. They were detained at Gwader fourteen or fifteen days by orders from the Government of India, in consequence of the report of disturbances at Kej, where the Governor, appointed by the Khan of Kelat, had been driven away by the inhabitants. Their journey to Jalk, a place never before visited by a European, was uneventful, only diversified by continual quarrels with the camel-drivers, who persisted in attempting to follow the ordinary roads instead of that along the frontier. The country passed through consisted of narrow valleys running east and west, and separated by very arid ridges. A bout the middle of March they reached Jalk, in latitude $27^{\circ} 36^{\prime}$ (45 further south than laid down on maps), which was the limit of their journey north. It had been originally intended to join Sir F. Goldsmid in Seistan, marching across the desert, but the lateness of the season and the absolute refusal of the camel-drivers to accompany them, rendered this impossible. They therefore turned westward to Bampoor, across the mountains of Beluchistan. From thence they proceeded to Bam, from there to Kerman and Shiraz, and finally returned to 'Teheran in July. The country from Jalk to Bampoor was the most fertile and populous part of Central Beluchistan. The only European who had previously visited this district was Sir Henry Pottinger, who, in 1809, travelled through it disguised as an Indian horsedealer, making his journeys principally by night, and going in continual fear 